\title{
A Study on Development of Nutrigenomics Premix Powder
}

\author{
Ruchi Yadav ${ }^{1}$, Sunita Mishra ${ }^{2}$ \\ ${ }^{1}$ M.Sc. Student, Department of Food and Nutrition, School For Home Sciences, Babasaheb Bhimrao Ambedkar University (A Central \\ University), Vidya Vihar, Rae Bareli Road, Lucknow-226025(U.P.), India Lucknow \\ ${ }^{2}$ Dean and Head, Department of Food and Nutrition, School For Home Sciences, Babasaheb Bhimrao Ambedkar University (A Central \\ University), Vidya Vihar, Rae Bareli Road , Lucknow-226025(U.P.), India Lucknow
}

\begin{abstract}
Nutrigenomics are nutrition based on genetic variation. nutrigenomics has also been described by the influence of genetic variation on nutrition . for those who suffer from genome related metabolic diseases or disorders, one of the treatment genome related metabolic diseases. Nutrigenomics health food-carrot, ginger, basil (tulsi) and soya bean having the properties that prevent the gene related metabolic diseases. Tulsi having antioxidant properties, maintain good cholesterol and also having anti-diabetic properties, tulsi extract is highly effective as hepatoprotective. Similarly ginger and soya bean having biological activities anticonvulsant, analgesic, antibacterial, gastric antisecretory, antiulcer, antifungal, antitumor, anti-inflammatory, antiallergenic and other activities, soyabean contain no starch and good source of protein for diabetic person. Carrot is rich in carotenoid, vitamin A and other important bioactive compounds. In this study used tulsi, ginger, soya bean and carrot to develop premix which help to decrease risk of genome related metabolic disorders.
\end{abstract}

Keywords: nutrigenomics, nutrition, genetic genome, health food, antioxidant, antitumor, anti-inflammatory, anticonvulsant, antibacterial, hepatoprotective

\section{Introduction}

Nutrigenomics is the study of the effects of bioactive compounds from food on gene expression. Several studies demonstrate that individual compounds, as well as complex mixtures of chemicals, derived from food alter the expression of genes in the human body. Bioactive present in food alter the concentration of specific proteins directly which associated with human diseases. Several human diseases is due to genetic variation result in multiple problems which are associated with many diseases including cardiovascular disease, arthritis, diabetes, hypertension, obesity, cancer, asthma, dermatitis etc. Food derived components play an active role in prevention of these types of diseases. Such biologically active compounds include carotenoid, dietary fibre, vitamins and minerals.

Carrot (Daucus carota) is a root vegetable that is often claimed to be the perfect health food. it is usually orange in colour, though purple, red, white, yellow varieties exist. It is crunchy, tasty and highly nutritious. Carrots are particularly good source of beta-carotene, fibre, vitamin $\mathrm{K}$, potassium and antioxidants. Carrots have number of health benefits. The consumption of carrot and its products is increasing steadily due to its recognition as an important source of natural antioxidants having anticancer activity.

Carotenoid carrot is one of the important root vegetable rich in bioactive compounds like carotenoid, dietary fibres with appreciable levels of several other functional components having significant health promoting properties. Carotenoid in food as natural pigments. Carotenoid is present itracellularly and their actions involve in the regulation of gene expression or effect cell functions like inhibition of monocyte adhesion and platelet activation. These biological effects are independent of pro- vitamin A activity and have been attributed to the antioxidant property of carotenoid, through deactivation of free radicals and single oxygen quenching.

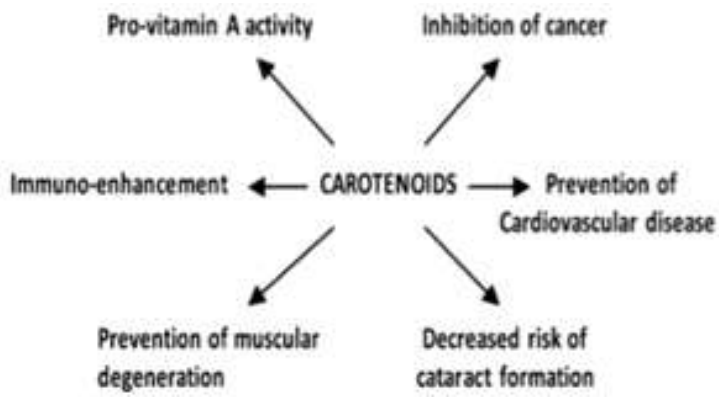

Figure 1: Health promoting functions attributed to carotenoids

Caroot intake may also enhance the immune system, protect against stroke, high blood pressure, osteoporosis, cataracts, arthritis, heart diseases, bronchial asthma and urinary tract infection (Beom et al. 1998; Sun et al. 2001; Seo and Yu 2003). Carotenoid also act as free-radical scavenger and very important for health (Bast et al. 1998; Bramley 2000). D'Odorico et al. (2000).

Have shown that the presence of $\alpha$ - and $\beta$-carotene in blood has a protective effect against atherosclerosis. Nocolle et al. (2003) has demonstrated that high carotenoid diet is associated with a reduced risk of heart disease.

Dietary fibres Dietary fibre is indigestible complex carbohydrate found in structural components of plants. They cannot be absorbed by the body and therefore, have no calorific value however, the health benefits of eating fibre rich diet are immense including prevention of constipation, regulation of blood sugar, protection against heart diseases, reducing high level of and prevention of certain form of cancers.

\section{Volume 6 Issue 12, December 2017}




\section{International Journal of Science and Research (IJSR) \\ ISSN (Online): 2319-7064}

Index Copernicus Value (2016): 79.57 | Impact Factor (2015): 6.391

Ginger is the underground rhizome of zingiber officinale perennial plant and is one of the world's most popular medicinal spices. Ginger also claims for use as anti-vomiting and anti-sickness agent. Ginger extracts have been extensively studied for a broad range of biological activities including antibacterial, anticonvulsant, analgesic, antiulcer, gastric antisecretory, and antitumor, antifungal, antifungal, antiallergenic, anti-inflammatory and other activities. The ginger plant has a perennial, tuberous root or rhizome; the stem are erect, oblique, round, annual and invested by smooth sheaths of the leaves, 2or 3 feet in height. Ginger rhizome is typically consumed as fresh paste, dried powder, slices preserve in syrup, candy or for flavouring of tea. In many countries specially in India and china, fresh ginger is used to prepare vegetable and meat dishes and as flavouring agent in beverages and many other food preparation. The underground stem or rhizome of this plant has been also used as a medicine in Asian, Indian, Arabic herbal traditions since ancient times (Altman and Marcussen, 2001).

Some phinolic substances present in ginger process to strong anti-inflammatory ands anti-oxidative properties and exert substantial anti-carcinogenic and anti-mutagenic activities.

Tulsi is the medicinal plants are widely used by the traditional medical practitioners for curing various diseases in their day to day practice. In traditional system of medicine, different parts (leaves stem, flower, rot, seed and even whole plant) of Ocimum sanctum Linn (known as Tulsi in Hindi), a small herb seen throughout India, have been recommended for the treatment of bronchitis, bronchial asthma, malaria, diarrhoea, dysentery, skin disease , arthritis, painful eye disease, chronic fever, insect bite etc. The Ocimum sanctum L. Has been also suggested to possess antifertility, anticancer, antidiabetic, antifungal, antibacterial, hepatoprotective, cardio protective, antiemetic, antispasmodic, analgesic, adaptogenic and diaphoretic actions.

Eugenol (1-hydroxy-2-methoxy-4-allylbenzene), the active constituent present in Ocimum sanctum L., has been to be largely responsible for the therapeutic potentials of tulsi.

Soya bean (Glycine max) is a species of legume native to East Asia, widely grown for it edible bean which has numerous uses the plant, classed as an oil seed rather than a pulse by the United Nation Food and Agriculture Organization, produces significantly more protein per acre than most other uses of land.

Fat free soya bean meal is a significant and cheap source of protein for animal feeds and many packaged meal. For example soya bean products such as textured vegetable protein (TVP) are ingredients is many meat and dairy substitutes. The bean contains significant amounts of phytic acid, dietary minerals and vitamin B. Soya vegetable oil used in food and industrial applications, is other product of processing the soya bean crop.

Soya bean are also an excellent source of molybdenum and copper. They are many good source of manganese, phosphorous and protein as well as good source of iron, omega-3 fatty acid, dietary fibre, vitamin B2, magnesium, vitamin $\mathrm{K}$ and potyassium. Past several year of clinical and scientific evedences have revealed the benefits of the soy components against metabolic disorders (cardio- vascular, diabetes and obesity etc.) as well as other chronic diseases (cancer, osteoporosis, menopausal syndrome and anaemia etc.).

\section{Objective}

To standardized and develop nutrigenomics Premix Powder.

\section{Method and Material}

The experiment was carried out in the research laboratory of the Department of Food and Nutrition, School for Home Sciences, Babasaheb Bhimrao Ambedkar University Lucknow. The different materials used in the experiments and technique.

The required sample for the experiment is carrot $(3 \mathrm{~kg})$, soya bean $(1 \mathrm{~kg})$, tulsi $(1 / 2 \mathrm{~kg})$, ginger $(250 \mathrm{gram})$. Raw materials i.e. carrot, tulsi, ginger, soyabean were procured from the local market of the Lucknow city. The procuring was done in single a lot to avoid variation and compositional differences so that quality differences could rule out.

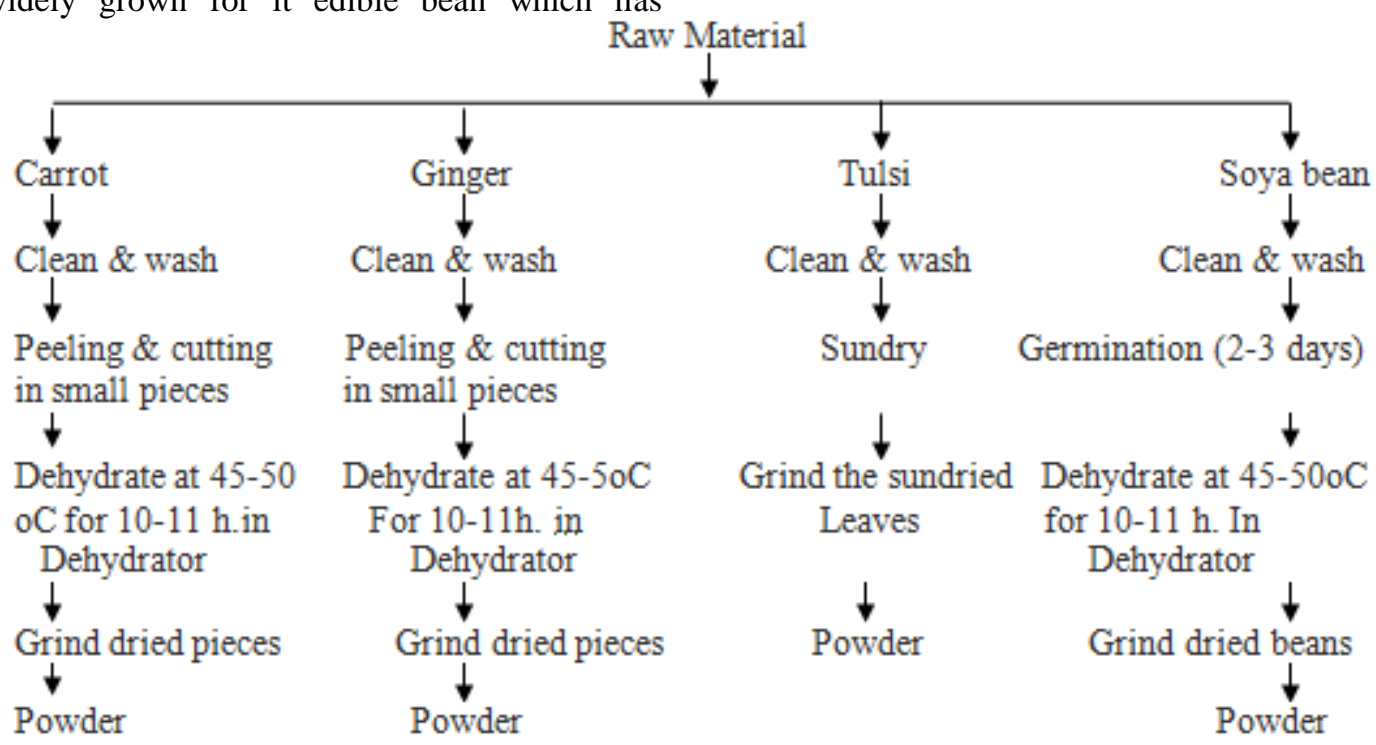

Figure 2: Processing of Raw material

Volume 6 Issue 12, December 2017 www.ijsr.net 


\section{International Journal of Science and Research (IJSR) \\ ISSN (Online): 2319-7064}

Index Copernicus Value (2016): 79.57 | Impact Factor (2015): 6.391

Collection of raw material, cleaned and washed them. Peeling and cutting in small pieces of carrot and ginger and dehydrate at $45-50 \mathrm{oC}$ for $10-11 \mathrm{~h}$ in dehydrator, put soyabean for 2-3 days to germination after germination dehydrate at $45-50 \mathrm{oC}$ for $10-11 \mathrm{~h}$ in dehydrator and tulsi leaves sundry. All dried ingredients grind in grinder for made powder.

These premix powder having properties which help to decrease the risk of gene related diseases. We can made many value added food products using premix powder. Such as in this study value added products prepared i.e. Aloo tikki, Dalia, Cheela and nutri powder.

\section{Conclusion}

Biochemically carrot is rich source of beta-carotene, fibre and many essential micronutrients and functional ingredients. The presence of high concentrations of carotenoid, especially beta-carotene in carrot roots makes them to inhibit cancers, free radical scavengers, antimutagenic and immune enhancers. Whereas ginger consist of non-volatile pungent compounds such as the gingerols, shogoals, paradols and gingerone that produce a "hot" sensation in mouth. It has also anti-oxidant and antiinflammatory activities that interfere with carcinogenic process and mutagenic activities. Carrot and ginger being perishable and seasonal, these are not possible to readily to make it available throughout the year. Dehydration of carrot and ginger during the main growing season is one of the important alternatives of preservation to further develop value added products throughout the year. Tulsi and soya bean mostly available in all seasons both are also help to decrease the risk of metabolic diseases. Soya bean is good source of omega-3 and 6 fatty acid which are beneficial for hearty health and tulsi is most widely used as a medicine. The premix powder s profitably be utilized to develop value added products. Further supplementation of food like bread, biscuit, cake etc.

\section{References}

[1] Anon (1952) The wealth of India: raw materials, vol 3. Council of Scientific and Industrial Research, New Delhi, pp 20-21

[2] Anon (1976) The wealth of India. Raw materials, vol 3. Council of Scientific and Industrial Research, New Delhi, pp 21-22

[3] Ayres JE, Fishwick MG, Land DG, Swain T (1964) Offflavours of dehydrated carrot stored in oxygen. Nature 203:81-82

[4] Babic I, Amiot MJ, Ngugen-The C, Aubert S (1993) Changes in phenolic content in fresh, ready-to-use and shredded carrots during storage. J Food Sci 58:351-356

[5] Banga R, Bawa AS (2002) Studies on dehydration of grated carrots. J Food Sci Technol 39:268-271

[6] Castermiller JJM, West CE (1998) Bioavailability and bioconversion of carotenoids. Ann Rev Nutr 18:19-38

[7] Chandler LA, Schwartz SJ (1998) Isomerization and losses of trans beta-carotene in sweet potatoes as affected by processing treatments. J Agric Food Chem 36:129-133
[8] Chen BH, Tang YC(1998)Processing and stability of carotenoid powder from carrot pulp waste. J Agric Food Chem 46:2312-2318

[9] Chen BH, Chen TM, Chein JT (1994) Kinetic model for studying the isomerization of alpha and beta-carotene during heating and illumination. J Agric Food Chem 42:2391-2397

[10] Chen BH, Peng HY, Chen HE (1995) Changes of carotenoids, colour and vitamin A contents during processing of carrot juice. J Agric Food Chem 43:19121918

[11]Chiang JC, Singh B, Salunkhe DK (1971) Effect of water quality on canned carrots, sweet cherries and apricot. J Am Soc Hortic Sci 96:353-356

[12] Cruess WV (1958) Commercial fruit and vegetable products. McGraw Hill, New York

[13]D'Odorico A, Martines D, Kiechl D, Egger G, Oberhollenzer B, Bonvicini P, Sturniolo GC, Naccarato R, Willeit J (2000) High plasma levels of alpha- and beta-carotene are associated with a lower risk of artherosclerosis-results from the bruneek study. Artherosclerosis 153:231-239

[14] De Sa MC, Rodriguez-Amaya DB (2004) Optimization of HPLC quantification of carotenoids in cooked green vegetables - comparison of analytical and calculated data. J Food Compos Anal 17:37-51

[15] Ghodke Y, Chopra A, Shintre P, Puranik A, Joshi K, Patwardhan B (2011) Profiling single nucleotide polymorphisms (SNPs) across intracellular folate metabolic pathway in healthy Indians. Indian J Med Res 133:274-279

[16] Ghosh D (2009) Future perspectives of nutrigenomics foods: benefits vs. risks. Indian Journal of Biochemistry \& Biophysics 46:31-36

[17] Ghosh D (2010) Personalised food: how personal is it? Genes Nutr 5:51-53 Ghosh K, Gorakshakar A (2010) Integration of modern genetic knowledge and technology into public health in India. Indian Journal of Human Genetics 16:45-46

[18] Hosomi R (2011) Effect of combination of dietary fish protein and fish oil on lipid metabolism in Rats. J Food Sci Technol. doi:10.1007/ s13197-011-0343-y

[19] Hossain P, Kawar B, Nahas ME et al (2007) Obesity and diabetics in the developing world-A growing challenge. N Engl J Med 356:213-215

[20] Hyman M (2006) Book on Ultra-metabolism: the simple plan for automatic weight loss. Atria Books, New York, p 24

\section{Volume 6 Issue 12, December 2017}

